\title{
Dampak Kenaikan Harga Tiket Pesawat Terhadap Return dan Harga Saham pada PT. Garuda Indonesia Tbk di Bursa Efek Indonesia
}

\author{
Agung Anggoro Seto ${ }^{1)}$, Dian Septianti ${ }^{2)}$ \\ ${ }^{1), 2)}$ Program Studi Manajemen Universitas Tridinanti Palembang \\ Jalan Kapten Marzuki No. 2446 Kamboja Palembang Kode Pos 30129 \\ Email : agung.anggoro.seto@univ-tridinanti.ac.id ${ }^{1)}$,dian_septianti@univ-tridinanti.ac.id ${ }^{2}$
}

\begin{abstract}
This research aims to analyze the impact of the price increase of airfare against return and the stock price of PT. Garuda Indonesia Tbk. This type of research is comparative. The Data used in this research is the secondary return and stock price of the weekly PT. Garuda Indonesia TBK in Indonesia Stock Exchange, with the amount of data 21 weeks before and 21 weeks after the price increase of airfare. Data analysis Model used the paired sample t-test. The results showed that there was no return on shares of PT. Garuda Indonesia TBK before and after the price increase of the airline ticket with a significance value of 0.887. The results also showed that there was a difference in the stock price of PT. Garuda Indonesia TBK before and after the price increase of the airline ticket with a significance value of 0.000. Where the stock price after the increase of the average airline ticket price is greater Rp. 239.143. The difference in the stock price of PT. Garuda Indonesia TBK. Before and after airfare increases due to investor perception or positive sentiments that assess the price increase in the aviation industry will benefit Airline companies. The high investor confidence and improvement of management system is believed to affect the investor's desire to invest in PT. Garuda Indonesia TBK So it has a significant impact on the price increase of PT. Garuda Indonesia TBK Post Airfare increases.
\end{abstract}

Keywords : Return, Stock Price, Price Airfare

\begin{abstract}
ABSTRAK
Penelitian ini bertujuan untuk menganalisis dampak kenaikan harga tiket pesawat terhadap return dan harga saham PT. Garuda Indonesia Tbk. Jenis penelitian adalah komparatif, data yang digunakan pada penelitian ini adalah sekunder berupa return dan harga saham mingguan PT. Garuda Indonesia Tbk di Bursa Efek Indonesia, dengan jumlah data sebanyak 21 minggu sebelum dan 21 minggu sesudah kenaikan harga tiket pesawat. Model analisis data yang digunakan paired sample t test. Hasil penelitian menunjukkan tidak terdapat perbedaan return saham PT. Garuda Indonesia Tbk sebelum dan sesudah kenaikan harga tiket pesawat dengan nilai signifikansi sebesar 0,887. Hasil penelitian juga menunjukkan bahwa terdapat perbedaan harga saham PT. Garuda Indonesia Tbk sebelum dan sesudah kenaikan harga tiket pesawat dengan nilai signifikansi sebesar 0,000. Dimana harga saham setelah kenaikan harga tiket pesawat rata-rata lebih besar Rp. 239,143 Adanya perbedaan harga saham PT. Garuda Indonesia Tbk. sebelum dan sesudah kenaikan harga tiket pesawat disebabkan oleh persepsi investor atau adanya sentimen positif yang menilai kenaikan harga tiket pada industri penerbangan akan menguntungkan bagi perusahaan penerbangan. Tingginya kepercayaan investor dan perbaikan sistem manajemen diyakini berpengaruh terhadap keinginan investor untuk berinvestasi di PT. Garuda Indonesia Tbk sehingga berdampak signifikan terhadap peningkatan harga saham PT. Garuda Indonesia Tbk pasca kenaikan harga tiket pesawat.
\end{abstract}

Kata kunci: Return, Harga Saham, Harga Tiket 


\section{Pendahuluan}

Era modern saat ini tidak dapat dilepaskan dari mobilitas masyarakat. Setiap orang dituntut untuk mobile dalam melaksanakan aktivitas sehari-harinya. Untuk mendukung mobilitas masyarakat, maka diperlukan moda transportasi yang mampu menunjang kebutuhan masyarakat dalam setiap aktivitasnya.Salah satu moda transportasi yang cukup mobile untuk mendukung mobilitas masyarakat adalah industri penerbangan.

Industri penerbangan adalah salah satu industri yang dinilai paling mobile, hal ini disebabkan industri penerbangan mampu menjangkau daerah-daerah yang memiliki jarak cukup jauh dengan waktu yang singkat. Jika dibandingkan dengan moda transportasi lainnya seperti transportasi darat maupun laut, industri penerbangan memiliki kelebihan pada sisi efisiensi waktu tempuh dibandingkan moda transportasi darat dan laut. Kelebihan efisiensi waktu serta didukung dengan harga yang relatif bersaing inilah yang membuat masyarakat di Indonesia yang membutuhkan mobilitas untuk mendukung aktivitas sehari-harinya lebih memilih menggunakan transportasi udara dibandingkan jenis transportasi lainnya. Hal ini membuat transportasi udara semakin populer dikalangan masyarakat.

Namun pada awal tahun 2019, beberapa maskapai penerbangan memberlakukan aturan yang kurang populer dimata masyarakat yaitu dengan menghapuskan pelayanan bagasi gratis, sehingga konsumen harus membayar sejumlah uang ketika membawa barang dengan menggunakan fasilitas bagasi. Tidak cukup sampai disitu, masih di awal tahun 2019 beberapa maskapai penerbangan menaikkan tarif jasa penerbangan untuk beberapa rute penerbangan. Kenaikan tiket pesawat ini menurut beberapa pengelola maskapai penerbangan disebabkan oleh beberapa beban operasional yang meningkat seperti biaya Passenger Service Charge (PSC) yang mengalami kenaikan hampir $130 \%$, biaya bahan bakar yang tidak menentu yang menyesuaikan dengan harga minyak dunia serta kenaikan upah minimum karyawan yang terjadi hampir setiap tahun (Inaca, 2019).

Kenaikan tarif disertai dengan tidak adanya bagasi gratis dibeberapa maskapai penerbangan membuat masyarakat yang sebelumnya cukup ramai menggunakan jasa penerbangan menjadi berkurang. Permintaan akan tiket pesawat menurun disertai penurunan jumlah pengunjung di beberapa bandar udara.

Menurut data Badan Pusat Statistik (BPS) jumlah penumpang angkutan udara tujuan domestik turun $15,5 \%$ dari 6,6 juta pada Januari 2019 menjadi 5,6 juta pada Februari 2019. Secara tahunan jumlah penguna angkutan udara juga menurun sebanyak $15,4 \%$ pada periode Januari - Februari tahun 2019 dibandingkan periode yang sama di tahun 2018 .

Kenaikan tarif penerbangan tidak hanya berdampak pada turunnya permintaan akan jasa penerbangan melainkan juga menjadi pemicu terjadinya inflasi dibeberapa daerah. Kontribusi kenaikan harga terhadap inflasi dibeberapa daerah inilah yang memicu pemerintah turun tangan untuk mengatur batas atas dan batas bawah harga tiket pesawat terbang.

Jika ditelaah lebih dalam lagi, kenaikan harga tiket pesawat terbang sangat mungkin berimbas pada penurunan demand yang dapat menimbulkan sentimen negatif terhadap harga saham perusahaan penerbangan di Bursa Efek Indonesia. Sentimen negatif ini cukup beralasan karena dengan penurunan demand jasa penerbangan akan mengerus pendapatan operasional dan pendapatan bersih perusahaan penerbangan yang berakibat pada kemungkinan penurunan return saham. Jika terjadi penurunan return saham, akan menimbulkan keraguan bagi investor yang akan berinvestasi serta menghasilkan sentimen negatif terhadap saham itu sendiri.

Namun kenaikan harga tiket juga memungkinkan investor untuk berinvestasi di saham-saham perusahaan penerbangan karena ekspektasi kenaikan harga tiket dapat mendorong pencapaian laba yang lebih besar dari perusahaan penerbangan.

Salah satu perusahaan penerbangan yang saat ini beroperasi di Indonesia adalah PT. Garuda Indonesia Tbk. PT. Garuda Indonesia Tbk. merupakan perusahaan penerbangan yang mayoritas sahamnya dimiliki oleh pemerintah Indonesia. Sama seperti perusahaan penerbangan lainnya PT. Garuda Indonesia Tbk juga mengambil langkah menaikkan harga tiket jasa penerbangannya untuk menutupi besarnya biaya operasional.

Menaikkan harga merupakan salah satu strategi yang dapat dilakukan oleh perusahaan penerbangan guna menutupi biaya operasional yang besar, namun kenaikan harga yang diikuti dengan penurunan jumlah permintaan akan jasa penerbangan dapat mengakibatkan sentimen negatif terhadap harga dan return saham PT Garuda Indonesia Tbk dimata investor. Namun disisi lain kenaikan harga tiket juga dapat saja dinilai sebagai positif bagi beberapa investor yang percaya bahwa dengan menaikkan harga tiket dapat memperbaiki keuangan dari perusahaan penerbangan yang beroperasi. Untuk membuktikan apakah terjadi sentimen negatif atau positif akibat dari kenaikan harga jual tiket pesawat terhadap harga dan return saham PT. Garuda Indonesia Tbk maka perlu dilakukan kajian mendalam mengenai dampak kenaikan tiket pesawat terhadap return dan harga saham PT. Garuda Indonesia Tbk.

\section{A. Saham dan Harga Saham}

Menurut Husnan (2008) saham adalah bukti kepemilikan modal dari pihak yang memiliki untuk mendapatkan bagian dari keuntungan atau kekayaan dari organisasi yang menerbitkan saham tersebut dengan beberapa kemungkinan pemilik modal untuk menjalankan haknya. Dengan kata lain saham merupakan tanda kepemilikan seorang investor atas investasi yang dilakukannya pada suatu asset yang dimiliki oleh organisasi.

Menurut Jogiyanto (2008) Harga saham adalah nilai jual saham di bursa pada suatu periode dimana besarannya ditentukan oleh pelaku pasar serta besarnya 
penawaran dan permintaan saham itu sendiri. Sedangkan menurut Bringham dan Houston (2011) harga saham menentukan kekayaan pemilik saham. Dimana harga saham diperiode tertentu akan bergantung pada arus kas yang diekspektasikan oleh investor dimasa yang akan datang.

Widoatmojo (2005) menyebutkan bahwa terdapat beberapa jenis harga saham yaitu:

a. Harga Nominal

Yaitu harga yang tercantum dalam sertifikat saham yang ditetapkan oleh emiten.

b. Harga Perdana

Harga pada saat saham dicatatkan pertama sekali pada bursa.

c. Harga Pasar

Harga jual antara investor yang satu dengan investor lainnya setelah saham tersebut tercatat di bursa.

d. Harga Pembukaan

Harga yang ditetapkan oleh penjual atau pembeli pada saat bursa dibuka.

e. Harga Penutupan

Harga yang ditetapkan oleh penjual danpembeli pada saat akhir bursa.

f. Harga Tertinggi

Harga yang paling tinggi yang terjadi pada hari bursa.

g. Harga terendah

Harga yang paling rendah yang terjadi pada hari bursa.

h. Harga rata-rata

Rata-rata dari harga saham yang terjadi pada hari bursa.

\section{B. Return Saham}

Return merupakan imbalan yang diperoleh dari investasi (Halim, 2005). Return dibedakan menjadi dua yaitu return yang telah terjadi (actual return) yang dihitung berdasarkan data historis, dan return yang diharapkan (expected return) akan diperoleh investor dimasa depan. Dua komponen Return yaitu untung/rugi modal (capital gain /loss) dan imbal hasil (yield). Capital gain/loss merupakan keuntungan (kerugian) bagi investor yang diperoleh dari kelebihan harga jual (harga beli) di atas harga beli (harga jual) yang keduanya terjadi dipasar sekunder.

Secara sistematis, perhitungan return saham menurut Jogiyanto (2009) adalah sebagai berikut:

Return saham $=(P t-P t-1+D \mathrm{t}) / P t-1$

Sedangkan return saham menurut Brigham dan Houston (2011) adalah sebagai berikut :

Return saham $=(P 1-P 0) / P 0$

Dimana:

$P t$ atau $P 1=$ Price, yaitu harga untuk waktu $\mathrm{t}$

$P t-1$ atau $P 0=$ Price, yaitu harga untuk waktu sebelumnya

$D t$

$=$ Dividen periodik
Karena pada laporan keuangan telah diketahui harga penutupan pada perusahaan setiap tahunnya dan karena tidak semua perusahaan membagikan dividen secara periodik sehingga pada penelitian ini penulis menggunakan rumus return saham yang di ambil dari Brigham dan Houston (2011) untuk memudahkan peneliti dalam menghitung return saham tersebut.

\section{Penelitian Terdahulu}

Beberapa penelitian terdahulu yang berhubungan dengan penelitian ini diantaranya dilakukan oleh Indarti dan Purba (2011) yang melakukan penelitian tentang perbandingan harga saham dan valume perdagangan saham sebelum dan sesudah stock split dimana hasil penelitiannya menemukan bahwa terdapat perbedaan harga saham dan volume perdagangan saham sebelum dan sesudah stock split.

Penelitian lainnya dilakukan oleh Pratama dkk (2014) yang melakukan penelitian yang berjudul analisis perbandingan abnormal return saham sebelum dan sesudah pengumuman right issue dimana hasil penelitiannya menunjukkan bahwa tidak terdapat perbedaan yang signifikan antara abnormal return sebelum dan sesudah right issue.

\section{Hipotesis}

Hipotesis pada penelitian ini adalah terdapat perbedaan return dan harga saham PT. Garuda Indonesia Tbk di Bursa Efek Indonesia sebelum dan sesudah menaikkan harga jual tiket pesawat.

\section{E. Kerangka Konseptual}

Menurut Sugiyono (2009), kerangka konseptual merupakan sintesa tentang hubungan antar variabel yang disusun oleh beberapa teori yang telah dideskripsikan. Sugiyono (2009), juga menegaskan bahwa hubungan antar variabel yang akan diteliti dapat dijelaskan melalui suatu model yang disebut dengan model penelitian.

Kerangka konseptual pada penelitian ini adalah sebagai berikut:

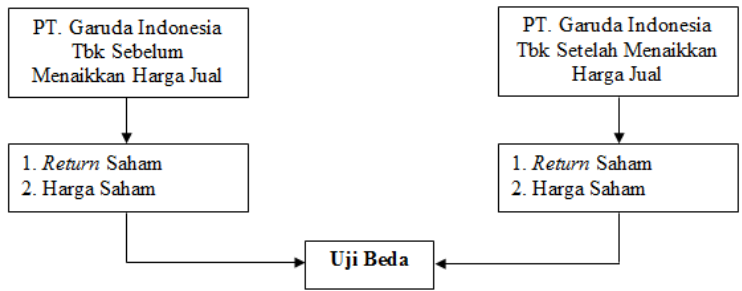

Gambar 1. Kerangka Konseptual Penelitian

\section{F. Metodologi Penelitian}

1. JenisPenelitian

Jenis penelitian adalah Komparatif yaitu penelitian yang bertujuan untuk mencari tahu dan membandingkan return dan harga saham PT. Garuda Indonesia Tbk sebelum dan sesudah kenaikan harga jual tiket pesawat.

2. Jenis Data

Data yang digunakan pada penelitian ini adalah data sekunder yaitu berupa data return dan harga saham 
mingguan PT. Garuda Indonesia Tbk di Bursa Efek Indonesia Mei 2018- Mei 2019.

3. Definisi Operasional

Definisi operasional dari variabel penelitian yang digunakan pada penelitian ini dapat dilihat pada Tabel 1.

Tabel 1. Definisi Operasional Variabel Penelitian

\begin{tabular}{|c|c|c|c|}
\hline Variabel & Definisi & Indikator & Skala \\
\hline Harga & Nilai jual saham & Harga & Rasio \\
\hline Saham & Garuda Indonesia & Penutupan & \\
\hline & Tbk di BEI. & Mingguan & \\
\hline Return & $\begin{array}{l}\text { Imbal hasil yang } \\
\text { diperoleh dari }\end{array}$ & Return & Rasio \\
\hline Saham & investasi pada & Saham & \\
\hline & saham PT. Garuda & Mingguan & \\
\hline & $\begin{array}{l}\text { Indonesia Tbk di } \\
\text { BEI }\end{array}$ & & \\
\hline
\end{tabular}

Sumber : Diolah Penulis (2019)

\section{Metode Analisis Data}

Metode Analisis data yang digunakan dalam penelitian ini adalah analisis kuantitatif yaitu suatu analisa yang dapat dinyatakan dalam bentuk angkaangka dan dihitung dengan menggunakan rumus statistik. Data-data yang dikumpulkan adalah data sekunder, time series dan cross section dan dilakukan dengan pengamatan dari saham PT. Garuda Indonesia Tbk di Bursa Efek Indonesia.

5. Teknik Analisis Data

Teknik analisis data pada penelitian ini adalah kuantitatif yang digunakan untuk menganalisis harga dan return saham PT. Garuda Indonesia Tbk di Bursa Efek Indonesia. Langkah-langkah dalam menganalisis data adalah sebagai berikut :

a. Pengukuran Return dan Harga Saham PT. Garuda Indonesia Tbk

Pengukuran return saham PT. Garuda Indonesia Tbk dilakukan dengan rumus :

Return saham $=(P 1-P 0) / P 0$

Dimana:

Pt atau $P 1 \quad=$ Price, yaitu harga untuk waktu $\mathrm{t}$

$P t-1$ atau $P 0=$ Price, yaitu harga untuk waktu sebelumnya

Sedangkan untuk pengukuran harga saham PT. Garuda Indonesia Tbk menggunakan harga penutupan (close price) yang tercatat di Bursa Efek Indonesia.

b. Melakukan Uji Normalitas

Uji Normalitas bertujuan untuk menguji apakah dalam sebuah model regresi, variabel dependen, variabel independen, atau keduanya mempunyai distribusi normal atau tidak. Model regresi yang baik adalah berdistribusi normal atau mendekati normal. Suatu data dikatakan mengikuti distribusi normal dilihat dari penyebaran data pada sumbu diagonal dari grafik (Ghozali, 2005).

Hipotesis :
Ho : Data berdistribusi normal

Ha : Data tidak berdistribusi normal

Dasar pengambilan keputusan :

Jika probabilitasnya (nilai sig) $>0,05$ maka Ho diterima.

Jika probabilitasnya (nilai sig) $\leq 0,05$ maka Ho ditolak.

c. Melakukan Uji Beda Paired Sample T Test

Uji paired sample t-test digunakan untuk menguji dua sampel berpasangan. Pada penelitian ini, uji paired sample t-test digunakan untuk menguji harga dan return saham sebelum dan sesudah kenaikan harga tiket pesawat.

Dasar pengambilan keputusan:

Jika nilai signifikansi $<0,05$ maka terdapat perbedaan antara sampel yang satu dengan sampel yang lainnya.

Jika nilai signifikansi $>0,05$ maka tidak terdapat perbedaan antara sampel yang satu dengan sampel yang lainnya.

\section{Pembahasan}

\section{A. Gambaran Singkat Objek Penelitian}

PT. Garuda Indonesia Tbk merupakan salah satu maskapai penerbangan di Indonesia yang berkantor pusat di Jakarta. Didirikan pada tanggal 31 Maret 1950. PT. Garuda Indonesia melakukan Initial Public Offering (IPO) pada tanggal 11 Februari 2011. Dimana tercatat IPO Price sebesar Rp. 750.

Hingga tahun 2019, jumlah saham yang beredar pada PT. Garuda Indonesia Tbk sebanyak 25,886 milyar lembar saham. Dengan kapitalisasi pasar sebesar 11,752 triliyun. Tercatat kepemilikan saham mayoritas PT. Garuda Indonesia Tbk dipegang oleh Republik Indonesia sebesar $60,54 \%$ sedangkan $25,62 \%$ dimiliki oleh Trans Airways dan sisanya 13,85\% dimiliki oleh publik.

\section{B. Hasil Penelitian}

1. Statistik Deskriptif Return dan Harga Saham PT. Garuda Indonesia Tbk

Untuk mengetahui dampak kenaikan harga tiket pesawat terhadap return dan harga saham PT. Garuda Indonesia Tbk. maka sangat penting untuk mendeskripsikan return dan harga saham PT. Garuda Indonesia Tbk.

Berikut ini adalah gambaran umum mengenai Harga PT. Garuda Indonesia Tbk sebelum dan sesudah terjadinya kenaikan harga tiket pesawat.

Tabel 2. Deskripsi Harga Saham PT. Garuda Indonesia

\begin{tabular}{|l|c|c|}
\hline \multicolumn{1}{|c|}{ Keterangan } & Sebelum & Sesudah \\
\hline $\mathrm{N}$ & 21 & 21 \\
\hline Minimum & 202 & 292 \\
\hline Maximum & 312 & 615 \\
\hline Mean & 222,19 & 461,33 \\
\hline S. Deviasi & 29,325 & 78.953 \\
\hline Variance & 859,962 & $6.234,456$ \\
\hline
\end{tabular}

Sumber : Diolah Penulis (2019) 
Secara umum harga saham PT. Garuda Indonesia Tbk setelah kenaikan harga tiket pesawat mengalami kenaikan. Hal ini dapat dilihat dari nilai rata-rata setelah kenaikan yaitu sebesar 461,33 lebih besar jika dibandingkan sebelum kenaikan yang hanya 222,19.

Berikut ini adalah gambaran umum mengenai return saham PT. Garuda Indonesia Tbk sebelum dan sesudah terjadinya kenaikan harga tiket pesawat.

Tabel 3. Deskripsi Return Saham PT. Garuda Indonesia

\begin{tabular}{|l|c|c|}
\hline \multicolumn{1}{|c|}{ Keterangan } & Sebelum & Sesudah \\
\hline $\mathrm{N}$ & 21 & 21 \\
\hline Minimum & $-0,727$ & $-0,1345$ \\
\hline Maximum & 0,2735 & 0,2707 \\
\hline Mean & 0,0169 & 0,0215 \\
\hline S. Deviasi & 0,0727 & 0,1146 \\
\hline Variance & 0,005 & 0,013 \\
\hline
\end{tabular}

Sumber : Diolah Penulis (2019)

Sama hal nya dengan harga saham, return saham rata-rata mingguan PT. Garuda Indonesia juga mengalami pasca kenaikan harga tiket pesawat. Dimana rata-rata return sebelum kenaikan harga tiket hanya sebesar 0,0169 atau $1,69 \%$, sedangkan setelah kenaikan harga tiket menjadi 0,0215 atau $2,15 \%$.

2. Uji Normalitas Return dan Harga Saham PT. Garuda Indonesia Tbk.

Hasil uji normalitas terhadap Return dan Harga Saham PT. Garuda Indonesia Tbk sebelum dan setelah terjadinya kenaikan harga tiket pesawat adalah sebagai berikut:

Tabel 4. Uji Normalitas Return dan Harga Saham PT. Garuda Indonesia Tbk Sebelum Kenaikan Harga Tiket Pesawat

Tests of Normality

\begin{tabular}{|l|c|c|c|c|c|c|}
\hline \multirow{2}{*}{} & \multicolumn{3}{|c|}{$\begin{array}{c}\text { Kolmogorov- } \\
\text { Smirnova }^{\text {a }}\end{array}$} & \multicolumn{3}{c|}{ Shapiro-Wilk } \\
\cline { 2 - 7 } & Statistic & df & Sig. & Statistic & Df & Sig. \\
\hline Harga & .285 & 21 & .000 & .648 & 21 & .000 \\
Return & .196 & 21 & .035 & .799 & 21 & .001 \\
\hline
\end{tabular}

a. Lilliefors Significance Correction

Sumber: Diolah Penulis (2019)

Tabel 5. Uji Normalitas Return dan Harga Saham PT. Garuda Indonesia Tbk Setelah Kenaikan Harga Tiket Pesawat

Tests of Normality

\begin{tabular}{|l|l|l|l|c|c|c|}
\hline \multirow{2}{*}{} & \multicolumn{3}{|c|}{$\begin{array}{c}\text { Kolmogorov- } \\
\text { Smirnov }\end{array}$} & \multicolumn{3}{c|}{ Shapiro-Wilk } \\
\cline { 2 - 7 } & Statistic & df & Sig. & Statistic & df & Sig. \\
\hline Harga & .203 & 21 & .024 & .953 & 21 & .389 \\
Return & .162 & 21 & .159 & .937 & 21 & .188 \\
\hline
\end{tabular}

a. Lilliefors Significance Correction

Sumber: Diolah Penulis (2019)
Berdasarkan hasil uji normalitas diketahui bahwa nilai signifikansi return dan harga saham PT. Garuda Indonesia Tbk sebelum dan sesudah kenaikan harga tiket pesawat $<0,05$ yang artinya semua data berdistribusi normal.

3. Uji Beda Paired Sample T Test Return Saham PT. Garuda Indonesia Tbk.

Untuk menjawab rumusan masalah pada penelitian ini, maka dilakukan uji beda Paired Sampel T-Test terhadap Return dan harga Saham PT. Garuda Indonesia Tbk.

Hasil uji paired sample t-test terhadap return saham PT. Garuda Indonesia Tbk adalah sebagai berikut:

Tabel 6. Uji Paired Sample T Test Return Saham PT. Garuda Indonesia Tbk.

Paired Samples Test

\begin{tabular}{|c|c|c|c|c|c|c|}
\hline \multirow{2}{*}{} & \multicolumn{2}{|c|}{ Paired Differences } & & & \\
\cline { 2 - 5 } & Mean & SD & $\begin{array}{c}\text { SE. } \\
\text { Mean }\end{array}$ & t & df & Sig. \\
\hline Pair 1 $\begin{array}{l}\text { Return_ } \\
\text { Stlah } \\
\text { Return_ } \\
\text { Sblm }\end{array}$ & .0046 & .1469 & .0320 & .144 & 20 & .887 \\
\hline
\end{tabular}

Sumber: Diolah Penulis (2019)

Berdasarkan hasil uji paired sample t-test pada return saham PT. Garuda Indonesia Tbk sebelum dan sesudah kenaikan harga tiket pesawat didapat hasil nilai signifikansi sebesar 0,887. Nilai 0,887 ini lebih besar dibandingkan 0,05. Hal ini berarti Ho diterima yang artinya tidak terdapat perbedaan antara return saham PT. Garuda Indonesia Tbk sebelum dan sesudah kenaikan harga tiket pesawat.

Hasil uji paired sample t-test juga menunjukkan selisih antara return saham PT.Garuda Indonesia Tbk sesudah dan sebelum kenaikan harga tiket pesawat hanya sebesar 0,0046 atau $0,46 \%$. Nilai $0,46 \%$ ini tidak cukup signifikan untuk membedakan return saham sebelum dan sesudah kenaikan harga tiket pesawat.

4. Uji Beda Paired Sample T Test Harga Saham PT. Garuda Indonesia Tbk.

Berikut ini adalah hasil uji beda Paired Sample t-test harga saham PT. Garuda Indonesia Tbk sebelum dan sesudah kenaikan harga tiket pesawat. 
Tabel 7. Uji Paired Sample T Test Return Saham PT. Garuda Indonesia Tbk.

Paired Samples Test

\begin{tabular}{|c|c|c|c|c|c|c|}
\hline & \multicolumn{3}{|c|}{ Paired Differences } & \multirow[b]{2}{*}{$\mathbf{t}$} & \multirow[b]{2}{*}{ df } & \multirow[b]{2}{*}{ Sig. } \\
\hline & Mean & SD & $\begin{array}{c}\text { SE. } \\
\text { Mean }\end{array}$ & & & \\
\hline \begin{tabular}{|rl} 
Pair 1 & Hrga \\
& Stlah- \\
& Hrga \\
& Sblm
\end{tabular} & $\begin{array}{c}239.14 \\
3\end{array}$ & $\begin{array}{c}92.27 \\
6\end{array}$ & $\begin{array}{c}20.13 \\
6\end{array}$ & $\begin{array}{c}11.87 \\
6\end{array}$ & 20 & .000 \\
\hline
\end{tabular}

Sumber: Diolah Penulis (2019)

Berdasarkan hasil uji paired sample t-test pada harga saham PT. Garuda Indonesia Tbk sebelum dan sesudah kenaikan harga tiket pesawat didapat hasil nilai signifikansi sebesar 0,000. Nilai 0,000 ini lebih kecil dibandingkan 0,05. Hal ini berarti Ho ditolak dan Ha diterima yang artinya terdapat perbedaan antara harga saham PT. Garuda Indonesia Tbk sebelum dan sesudah kenaikan harga tiket pesawat.

Hasil uji paired sample t-test juga menunjukkan selisih antara harga saham PT.Garuda Indonesia Tbk sesudah dan sebelum kenaikan harga tiket pesawat sebesar Rp. 239,143,- dimana harga saham sesudah kenaikan tiket lebih besar dibandingkan sebelum kenaikan tiket pesawat.

\section{Pembahasan}

1. Perbedaan Return Saham PT. Garuda Indonesia Tbk Sebelum dan Sesudah Kenaikan Harga Tiket

Return saham adalah proyeksi keuntungan yang akan diperoleh oleh investor sebagai imbal balik atas investasinya pada suatu saham. Return saham merupakan salah satu alat untuk menarik investor berinvestasi pada instrumen investasi.

Berdasarkan hasil penelitian tidak terdapat perbedaan return saham PT. Garuda Indonesia Tbk sebelum dan sesudah kenaikan harga tiket pesawat dengan nilai signifikansi sebesar 0,887 .

Hasil penelitian ini juga sejalan dengan hasil penelitian yang dilakukan oleh Pratama dkk (2014) yang melakukan penelitian yang berjudul Analisis perbandingan abnormal return saham sebelum dan sesudah pengumuman right issue dimana hasil penelitiannya menunjukkan bahwa tidak terdapat perbedaan yang signifikan antara abnormal return sebelum dan sesudah right issue.

2. Perbedaan Harga Saham PT. Garuda Indonesia Tbk Sebelum dan Sesudah Kenaikan Harga Tiket

Harga saham merupakan nilai jual saham PT. Garuda Indonesia Tbk saat perdagangan di Bursa Efek Indonesia

Berdasarkan hasil penelitian ditemukan bahwa terdapat perbedaan yang signifikan antara harga saham PT. Garuda Indonesia Tbk sebelum dan sesudah kenaikan harga tiket pesawat dengan nilai signifikansi sebesar 0,000

Adanya perbedaan harga saham PT. Garuda Indonesia Tbk. sebelum dan sesudah kenaikan harga tiket pesawat disebabkan oleh persepsi investor atau adanya sentimen positif yang menilai kenaikan harga tiket pada industri penerbangan akan menguntungkan bagi perusahaan penerbangan. Dan diantara beberapa perusahaan penerbangan, hanya PT. Garuda Indonesia Tbk yang merupakan perusahaan BUMN, sehingga menimbulkan kepercayaan investor untuk berinvestasi pada PT. Garuda Indonesia Tbk.

Selain itu berdasarkan laporan keuangan PT. Garuda Indonesia Tbk diketahui pada beberapa tahun terakhir terjadi perbaikan sistem manajemen yang berdampak pada membaiknya beberapa indikator fundamental PT. Garuda Indonesia Tbk.

Tingginya kepercayaan investor dan perbaikan sistem manajemen inilah yang diyakini berpengaruh terhadap keinginan investor untuk berinvestasi di PT. Garuda Indonesia Tbk sehingga berdampak signifikan terhadap peningkatan harga saham PT. Garuda Indonesia Tbk pasca kenaikan harga tiket pesawat.

\section{Kesimpulan}

Berdasarkan hasil penelitian didapat kesimpulan sebagai :

1. Tidak terdapat perbedaan return saham PT. Garuda Indonesia Tbk sebelum dan sesudah kenaikan harga tiket pesawat dengan nilai signifikansi sebesar 0,887 .

2. Terdapat perbedaan harga saham PT. Garuda Indonesia Tbk sebelum dan sesudah kenaikan harga tiket pesawat dengan nilai signifikansi sebesar 0,000.

\section{Daftar Pustaka}

Bringham, E. F. dan Joel F. Houston. 2011. Dasar-dasar Manajemen Keuangan.

Ghozali, Imam., 2005, Aplikasi Analisis Multivariate Dengan Program SPSS Edisi Ketiga, Semarang, Badan Penerbit Universitas Diponegoro.

Halim, Abdul. 2005. Analisis Investasi. Jakarta: Salemba Empat.

Hartono, J. 2008. Teori portofolio dan analisis investasi. Yogyakarta: BPFE.

Husnan, S., \& Enny, P. 2008. Dasar-Dasar Manajemen Keuangan, edisi pertama, cetakan pertama, edisi pertama, cetakan pertama. Penerbit: UPP AMP YKPN, Yogyakarta.

Inaca. 2019. INACA Nilai Permintaan Penurunan Harga Tiket Pesawat Sulit Diwujudkan. https://amp.katadata.co.id/berita/2019/05/07/inacanilai-permintaan-penurunan-harga-tiket-pesawatsulit-diwujudkan. Diakses pada tanggal 8 Mei 2019.

Indarti, I., \& Purba, D. M. B. 2012. Analisis perbandingan harga saham dan volume perdagangan saham sebelum dan sesudah stock split. Jurnal Ilmu Ekonomi ASET, 13(1).

Pratama, I., Surya, G., \& Sudhiarta, G. M. 2014. Analisis Perbandingan Abnormal Return Saham Sebelum dan Sesudah Pengumuman Right Issue. E-Jurnal Akuntansi Universitas Udayana, 3(3), 243-257. 
Sugiyono., 2009, Metode Penelitian Kuantitatif, Kualitatif, dan R\&D, Bandung, CV Alfabeta.

Widioatmodjo, S. 2005. Cara sehat investasi pasar modal. Elex Media Komputindo. 